\title{
GERMANY'S EURO CRISIS: PREFERENCES, MANAGEMENT, AND CONTINGENCIES
}

\author{
Michael Olender
}

Carleton University

\begin{abstract}
This article applies Moravscik's ideational liberalism to outline domestic and international influences on German state preference formation since the introduction of the euro and discusses the trends that distinguish German policy making and why they matter in the development of sustainable solutions to the ongoing euro crisis. The German government's ideational commitments to the European project and ordoliberal principles are found to be significant determinants in preference formation, but while its commitment to Europe has remained stable over time, its commitment to ordoliberalism has wavered. The government prefers to advance European integration in line with ordoliberal principles, though in times of crisis it hardens its ordoliberal stance. This article argues that Germany will go to great lengths to keep the Eurozone intact because it is part of a grand political project, but the government's prescription for fiscal austerity, which is underpinned by ordoliberal principles, sometimes exacerbates the euro crisis. Policy recommendations that favour flexibility are offered for Germany and other Eurozone countries.
\end{abstract}




\section{Introduction}

How much do economic and political ideas matter in Germany, the Eurozone's leading economy which is responsible for managing the ongoing euro crisis, and why has the crisis evolved the way that it has? This article investigates which ideational commitments inform the German government's preference formation on Economic and Monetary Union (EMU) and whether its preferences have changed over time. Austerity measures demanded by Germany and bailouts of indebted Greece, Ireland, and Portugal are evidence of two determinants of state preferences: commitments to ordoliberal principles ${ }^{1}$ and the European project. The academic literature on EMU does not come to a firm conclusion about which determinant holds more weight in the formation of German preferences (see, for instance, Kaltenthaler 2002), which means that the government's policy making during the crisis can be difficult to understand. Following a discussion about the two commitments, this article applies Andrew Moravcsik's ideational liberalism ${ }^{2}$ in two case studies-Germany breaking and revising the Stability and Growth Pact (SGP) between 2002 and 2005 and its management of the 2008-09 global financial crisis-and finds that Germany prefers advancing European integration according to ordoliberal principles, but while its commitment to the European project has remained stable over time, its commitment to ordoliberalism has wavered. Notably, in times of crisis the German government hardens its ordoliberal stance. Reflecting on insights from these studies, this article then argues that Germany will go to great lengths to keep the 17-country Eurozone intact because it is part of a grand political project, but the government's prescription for fiscal austerity, which is underpinned by ordoliberal principles, sometimes exacerbates the euro crisis. Understanding the coupling of commitments since 1999, when the euro was introduced as an accounting unit, and under which conditions one commitment may be prioritized could help policy makers reconceptualize strategies to address the crisis.

\footnotetext{
1. Ordoliberalism is a multifaceted economic ideology that has evolved over time. See Rieter and Schmolz (1993, 91-108) for a thorough discussion about how the Freiburg School—specifically Walter Eucken, Franz Böhm, and Hans Großmann-Doerth-developed the ideology in 1938-45 in opposition to the economic order established by National Socialism. See also Allen $(2005,205)$ for the Freiburg School's specific policy prescriptions and the "framework" philosophy of the school. See White (2012) for how ordoliberal policies resulted in the postwar economic miracle in West Germany. See Kitschelt and Streeck (2004) for details about how the German economic system, particularly with regard to the organization of capital and labour and the role of the state, adapted to events and evolved alongside changing conditions from the end of the Second World War until the beginning of the 21st century. See Allen (2010) for a discussion on Germany's economic performance from reunification through the first decade of the 21st century. For the purpose of this article, what matter are the economic, institutional, and political principles outlined in Dyson (2002, 177-78), since they influenced how German policy makers constructed EMU and continue to resonate. For the sake of simplicity, these principles will be together referred to as "ordoliberal principles" or "ordoliberalism."

2. This article recurs to Moravcsik's liberal theory of state preference formation and focuses on ideational liberalism (see Moravcsik 1997, 516-21, 525-28). Commercial liberalism and republican liberalism help explain foreign policy preferences, but there is much evidence against market incentives of domestic and transnational actors and rent seeking by privileged societal groups in the case of German state preference formation on EMU. Ideational liberalism is theoretically most interesting because the German government is overtly influenced by ideas when it comes to institution building and crisis management. Hence, ideational liberalism will be applied rather than the liberal theory that subsumes all three variants.
} 


\section{Ordoliberalism and the European Project}

Commitments to ordoliberal principles and the European project are linked to Germany's distinctive history, politics, and economics, which matter because the country has a central role in developing policies and designing treaties and institutions in Europe. Ordoliberalism originated at the University of Freiburg in the 1930s and has since evolved and come to be known as the German model of political economy that guides policy makers in their responses to events and change. Developed in opposition to the economic order established by National Socialism, the ideology has been dominant domestically since the end of the Second World War and has had a diverse influence. For example, it underpinned the social market economy that drove West Germany's strong economic performance until the 1990s and influences reunified Germany's policy on EMU. On the topic of EMU, Kenneth Dyson (2002, 177-78) explains that ordoliberalism is comprised of three main principles. First, to be sustainable, EMU must be a "stability community" based on economic convergence, which means prioritizing open and competitive markets, rules against bailouts, proscription of monetary financing of budget deficits, and strict rules on fiscal discipline. Second, specific policy problems are to be clearly assigned to actors or institutions that are responsible for solving them; in particular, the price stability mandate of the European Central Bank (ECB) is not to be undermined. Third, a strong euro depends on the ability of the European Union (EU) to project itself as "an autonomous political entity"; EMU, then, requires an acceleration of European political union by strengthening EU institutions and increasing the effectiveness of coordination. Ordoliberalism prescribes a long-term framework for monetary and fiscal policy as an "essential precondition for sustainable growth and employment" (186). In cases of unsustainable sovereign debt loads, it prescribes austerity measures, which are meant to "break the cycle of debt and the threat of insolvency, reassuring the private sector and thus triggering natural and sustainable growth," and proscribes expansionary state intervention, such as Keynesian stimulus (Guérot and Dullien 2012). Crucially, "[f]ailure to reach fiscal targets is seen as a political failure of will" (Guérot and Dullien 2012). Citing postwar and post-reunification experiences, Ulrike Guérot and Sebastian Dullien (2012) argue that "[i]n the German mind, postwar success is firmly linked to ordoliberal policies, even if the reality might be more complex than that. These central tenets that lay out how to run an economy are largely an article of faith across Germany." That ordoliberal principles have become ingrained in German decision making is a testament to the power of ideas and their relation to material outcomes.

The German government's commitment to the European project, here defined as the integration process, is based on Germany's history in the 20th century, and the euro is a focal point because of its role in locking countries into the project. As a country that has played an essential part in two world wars which resulted in its division and a divided Europe, Germany has a stake in the single currency and, relatedly, the continent's unity. It is widely understood that the politics which drove European integration since the creation of the European Coal and Steel Community in the 1950s until the creation of the EU was based on attempts by countries, particularly France, to embed Germany in a European institutional framework to dissuade it from reverting to its past nationalistic and militaristic ways. But it should be noted that former West German chancellor Konrad Adenauer intended to regain legitimacy through reconciliation and integration and former chancellor Helmut Kohl worked to embed West Germany and reunited Germany in networks of multilateral governance, international alliances, and economic interdependence (Chandler 2002, 202-03). Karl Kaltenthaler (2002, 69-73) finds that the 
German Chancellery and Foreign Ministry's geopolitical concerns drove European monetary integration until German reunification in 1990. After that, he argues, and through the 1990-91 Maastricht negotiations that concluded with decisions about moving forward with EMU and the institutional structure of the ECB and led to the signing of the Maastricht Treaty in 1992 and creation of the EU the following year, the German Bundesbank (considered ordoliberalism's "institutional epicentre" [Dyson 2002, 177]), Finance Ministry, and domestic financial and industry sectors together took the lead in shaping policy on monetary integration. Complementing Kaltenthaler's analysis, Peter Katzenstein (1997, 116-18, 123) contends that Germans prioritize "political responsibility" because of the "institutionalization of power" since the end of the Second World War and have become increasingly aware that their country's actions are made within a society of states. He says that Germany focuses on shaping rules and "tends to mobilize a bias favoring its policy in the long term" (120), which translates into regulative power. Katzenstein explains that following reunification,

[u]nderneath the "soft" power of institutional politics, newer, "hard" economic interests in the area of regulative politics express serious internal resource scarcities. These interests are beginning to supplant older, "hard" political interests that had aimed at the general stabilization of Germany's external environment . . . . This shift reflects new conditions at home and abroad and increases the weight of short-term interests in German policy. (1997, 121)

This perspective suggests that Kaltenthaler (2002) may be right in his argument. Katzenstein (1997, 122-23), however, goes on to argue that, in contrast to Britain and France, Germany's preference has been to advance political integration in Europe and strongly support the EU, specifically the European Parliament. He concludes that "we need to think not of Germany and Europe but of Germany in Europe . . . Germany in Europe is a political fact that will continue to define the international and national politics of the new Europe" (123).

It is clear that ordoliberalism informs German preference formation on EMU, but Katzenstein's conclusion suggests that Germany is deeply committed to the European project regardless of short-term domestic economic interests. Moreover, his point about Germany supporting the advancement of political integration in Europe reflects ordoliberalism's third principle, indicating that there may be overlap between economic and political ideational commitments. Germany's commitment to the European project evidently deserves more attention in analyses of state preference formation and policy making. Time horizons are certainly something to consider. In the short term, domestic economic interests may well be prioritized over political concerns according to national and international circumstances, but this does not mean that they will always be prioritized, especially in the medium and long term. A long-term study that assesses the commitments together could generate new knowledge about the German government's preferences about EMU over time. Findings could then be applied to trends during the euro crisis.

What follows are two case studies that assess Germany's commitments to ordoliberal principles and the European project since the introduction of the euro. The application of ideational liberalism to analyze state-society relations and international bargaining when Germany broke the SGP starting in 2002 and revised it between 2003 and 2005 and during Germany's management of the 2008-09 global financial crisis offers insight into the commitments that inform German preferences about EMU in contingency and crisis situations. 
The studies find that the commitments remain coupled, hence Germany's preference on EMUthe German government prefers to advance European integration according to ordoliberal principles - is generally stable over time. Germany's commitment to ordoliberalism became negotiable during the controversy over the SGP, yet its commitment to integration remained strong. During the global financial crisis, Germany hardened its ordoliberal stance, but this was ultimately for the benefit of Europe, in addition to itself and the global economy. The conclusions that Germany prefers to advance European integration according to ordoliberal principles, that these principles are up for negotiation during contingency situations, and that the government reverts to its ordoliberal tradition during times of crisis have implications for policy making on EMU in general. The fact that the government's commitment to ordoliberalism wavers while its commitment to the European project is unwavering is a significant finding because it helps to make sense of German policy making during the euro crisis and highlights areas where the government is able and unable to compromise.

\section{Breaking the Pact}

Kaltenthaler (2002, 81-85) implies that since reunification Germany has been committed to European integration in line with ordoliberal principles. This general trend continued through the creation of the euro as an accounting unit in 1999 until the introduction of bills and coins in 2002, but soon after, worsening domestic economic problems caused the country to break from its ordoliberal tradition. Believing that there needed to be something in place to ensure the stability of the euro when it launched, then German finance minister Theo Waigel in 1995 proposed the SGP, which can be considered a means to promote further European integration according to ordoliberal principles. The SGP, a set of legally binding fiscal rules and excessive deficit procedures designed to ensure governments attempt to balance their annual budgets, was concluded in 1996 and afterwards adopted by all EU Member States. Europe benefited from a cyclical economic boom between 1997 and 2000, which helped improve fiscal balances, but a low-growth trend began at the end of 2000. Portugal was the first country to breach the 60 percent limit on public debt in 2001, then Germany and France breached it the following year and lobbied to avoid punitive measures. On top of ongoing reunification costs, ${ }^{3}$ Germany experienced mounting public debt related to a fall in revenues from profit-related taxes, income taxes, social contributions with rising unemployment and wage moderation, and tax cuts, which was only partly offset by expenditure cuts (Dyson 2008, 151). Germany's public debt rose from 60.3 percent of gross domestic product (GDP) in 2002 to 67.5 percent in 2006; the country breached the SGP for four consecutive years (151). Growth policies became necessary. This was

3. See Wiesenthal (2004) for a discussion on the difficulties and costs of reunification. West Germany transferred markets and institutions to East Germany and expected a smooth transition and economic convergence to bolster Germany's strong international position, but from 1992 to 2002 the country experienced growth rates below its annual increases in productivity, resulting in rising unemployment, a weak economic performance overall, and a political stalemate over economic reform. East German socialist and economic structures were not organized to benefit from West German institutions and currency reform caused the appreciation of the East German Mark, leaving East German economic activity uncompetitive. The proper option for improving the macroeconomic situation was lowering wages and taxes while increasing the flexibility of the labour market and state regulation, but the electoral imperatives of parties and state governments resulted in fiscal transfers for wage equalization, perpetuating the stagnation of the overall German economy. Germany had the lowest growth rate of all EU countries from 1995 to 2009, growing only 16 percent; its resurgence after 2009 was due to increased exports to China, oilexporting states, and Eastern and Southern European countries following implementation of the painful Agenda 2010 reforms (Young and Semmler 2011, 7-8, 12-13). 
a contingency situation for Germany in which realizing legitimate domestic order, socioeconomic regulation, and redistribution led the government to be more flexible internationally on the topic of ordoliberalism and prioritize further integration.

The general trend that Germany has been committed to European integration in line with ordoliberal principles is nuanced by the fact that its commitment to ordoliberalism wavers. The election of a new government can reflect changes in domestic social identities. ${ }^{4}$ The centre-right Kohl government, which was strongly committed to both the European project and ordoliberalism, was replaced in 1998 by a centre-left coalition government of the Social Democratic Party of Germany (SDP) and the Greens. The newly elected government under Gerhard Schröder prioritized national interests that were tied less to European integration and even less to Germany's ordoliberal tradition. Internationally, it emphasized the centrality of the Franco-German relationship and favoured "multiple bilateralism" over multilateralism (Jeffery and Paterson 2004, 71). The government was most concerned, however, about the German economy. It was tasked with improving employment numbers and breaking Germany's cycle of indebtedness and low growth that had been persistent since reunification. Over its first term the government increasingly abandoned ordoliberal supply-side policies for fiscal policies that combined supply- and demand-side elements to support growth and employment and adopted a "neo-Keynesian" view that budget policy should not be pro-cyclical (Dyson 2008, 150-51). The shift away from ordoliberalism was possible because after 1999 the government did not have the same incentives to "bind in" the Bundesbank, the opposition and advice of which became less of an issue; the government therefore had more flexibility with domestic fiscal policy and the SGP $(150,152)$. The shift was also motivated by electoral concerns, internal party opposition to structural reforms and spending cuts, and political problems with Agenda 2010, the government's long-term (ordoliberal) program of deep cuts to social security and labour market reforms aimed to improve economic growth and reduce unemployment (151). Notably, neither the government nor the public attributed Germany's economic problems to the euro, a situation that "has its roots in the elite and public consensus on the euro as a fundamentally political project in Germany's vital national interests" $(158-59,163)$. These developments demonstrate that successive German governments are not bound by the country's ordoliberal tradition and with EMU realized, domestic social identities were characterized by the prioritization of national interests, which included the success of the European project.

The German government breached the SGP starting in 2002 because it restricted opportunities for reforms and economic growth, yet the government lobbied to revise the pact, reaffirming its commitment to the European project. Comparing international bargaining during negotiations on the SGP in 1996 to Germany's lobbying for reform of the pact in 2003 indicates that one ideational commitment can be prioritized over the other according to national circumstances. In 1996, Germany under Kohl insisted on near-automatic penalties for countries with excess deficits, a position supported by the Netherlands but rejected by France, the United Kingdom, Italy, and Spain as too rigid (Chandler 2002, 211). While Germany wanted central bankers to

4. Ideational liberalism views "the configuration of domestic social identities and values as a basic determinant of state preferences and, therefore, of interstate conflict and cooperation" (Moravcsik 1997, 525). Social identities are sets of individual preferences about the proper scope and nature of public goods provision that subsequently specify the nature of legitimate domestic order; political decision-making processes - which can be thought of as public goods that are shaped by social identities - are one of the essential elements of domestic public order (Moravcsik 1997, 525). In this article, the relevant social identities are the commitment of individuals and groups to particular political institutions and the nature of legitimate socio-economic regulation and redistribution (see Moravcsik 1997, 527-28). 
have maximum discretion in applying sanctions for excess deficits, France wanted ministers to have the last word (a position that was supported by the majority of countries), and there was contention over the definition of "exceptional circumstances" that would allow countries to escape being penalized (211). Germany's rigidity and penchant for penalties often makes bargaining tense, given that almost all other Eurozone countries prefer flexibility. An exchange of policy concessions balanced German demands for near-automatic sanctions and majority demands for ministers having the last word, but the SGP ultimately leaned toward German preferences and narrowly defined exceptional circumstances (211). These negotiations, the results of which could be considered a reconfiguration of state preferences, were a crucial diplomatic achievement for Germany and their outcome should have improved long-term Eurozone prospects - if only countries, including Germany, had adhered to the new rules.

In 2003, after deterioration in Germany's public finances had caused the European Commission to recommend to the EU's Economic and Financial Affairs Council (ECOFIN) to begin excessive deficit procedures, the Schröder government lobbied to ensure that ECOFIN vetoed the warning proposal and to rewrite the rules of the SGP. Other countries were not strongly committed to SGP rules and preferred flexibility, but Germany countered the weakening of the pact by assuming political responsibility and revising it. During the 2001-05 period, most countries were not complying with the SGP and ECOFIN did not penalize them, which further weakened the pact's credibility (Lorca-Susino 2010, 159). The German government adopted a position - opposed by the Bundesbank, but supported by the French government - that it

should be allowed flexibility in hard times to adjust budgetary policy to the economic cycle; that major reforms to labour markets and the welfare state (like Agenda 2010 in March 2003) should be taken into account in assessing the state of public finances because of their effects on long-term potential growth and employment; and that, if existing rules did not allow recognition of individual circumstances and Germany was being required to engage in ever more pro-cyclical savings, the rules needed to be renegotiated to make them more credible. (Dyson 2008, 151)

Germany and France, because of their greater voting weight in ECOFIN, were able to reform the pact to be more in line with their interests and more open to political interpretation (Chang 2006, 118-19). The SGP was formally revised in March 2005 to meet the Schröder government's demands to adapt the fiscal compliance rules to legitimize Germany's fiscal policy decisions since 2001, which increased the pact's flexibility for all Eurozone countries (Dyson 2008, 15152). The Bundesbank, ECB, and International Monetary Fund (IMF) considered the revised SGP, with an increased time period to implement corrections and a lengthy exceptional circumstances list, to be weak; the pact was unevenly respected after its adoption, despite enforcement efforts by the European Commission (Lorca-Susino 2010, 160). Germany's breaking of the SGP did not result in tensions with other countries, which desired less strictness, but the government's actions effectively set a new standard in the Eurozone - that fiscal rules could be broken without recourse. What is most important in this case, however, is that while Germany prefers to adhere to ordoliberal principles and can mobilize bias for its preferences, national circumstances can influence the country to largely abandon those principles, though it will assume political responsibility and advance integration in response. By prioritizing national interests and revising 
the SGP, Germany improved growth and increased employment while continuing to advance European integration, which demonstrates that its commitment to the European project can be prioritized over its commitment to ordoliberal principles.

\section{Managing Crisis}

The election of the centre-left "grand coalition" of the centre-right Christian Democratic Union/Christian Social Union (the Union) under Angela Merkel and centre-left SDP in 2005, perhaps explained by a partial reversion in domestic social identities, was followed by an improvement in German economic performance, which improved the Eurozone's overall fortunes and allowed Germany to reassert leadership. When the global financial crisis deepened in 2008 with the bankruptcy of American investment bank Lehman Brothers, the German government was thrust into a leadership role in international crisis management. Major drops in stock markets, a near collapse of the US banking system, and a credit squeeze and falling asset prices in Europe and the rest of the world resulted in a global recession that necessitated extraordinary action by Eurozone governments. Like the governments of many other developed and emerging market countries, they responded by providing rescue packages and increasing government spending, which significantly drove up deficits, in attempts to stem the consequences of the crisis (Verdun 2009, 233). Central banks including the ECB coordinated to lower interest rates and increase liquidity to banks. Economic growth in the Eurozone ended the year at 0.9 percent, reinforcing uncertainty (234). In 2009, German GDP contracted 5 percent compared to the previous year, reflecting a sharp decline in exports and domestic capital investment in the winter of 2008-09, and the German economy experienced its deepest recession since the Second World War (Dyson 2010, 400-01). During a time of prolonged uncertainty, Germany reverted to its traditional ordoliberal stance and strictly promoted further integration according to ordoliberal priniciples. In this crisis situation, Germany prioritized its commitment to ordoliberal principles in order to sustain or restore legitimate domestic order, socio-economic regulation, and redistribution but continued to advance European integration as well.

For the German government, ordoliberalism informed preference formation and its strategic response and effectively functioned as an interpretive framework that allowed it to manage and reduce uncertainty and develop proposals to address the crisis. A core executive group with Merkel at the helm saw its task as restoring stability first in the country and then Europe, with German banks a primary concern. The crisis prompted the rehabilitation of the social market economy after years of experimentation with a liberal market model, the restoration of the Bundesbank's reputation, and financial stability to gain new pre-eminence co-equal with price stability (Dyson 2010, 401). The government's responses were "framed by a mix of classical ordoliberal thinking with centre-Left political positioning," social priorities being education, research, and innovation (407). Germany's bank rescue was the largest in Europe and an unprecedented obligation for the government. German banks, which were engaged in international wholesale markets and asset-backed securities, were offered guarantees of $€ 400$ billion, and an $€ 80$ billion program was created to allow them to borrow from the government to increase equity (400-01; Schirm 2011, 55). Going against its ordoliberal tradition, the government implemented a short-term domestic stimulus program of around 3 percent of GDP in 2009-a package smaller than in other countries - that included emergency spending, large unemployment benefits, and government subsidies for the pay of workers who work fewer hours (Newman 2010, 158). It, however, explained that there would be no lasting reorientation of 
economic policy, measures taken during the crisis were exceptional, it intended to return to fiscal consolidation as soon as the crisis was over, and the introduction of a constitutional debt brake acted as a long-term guarantee (Zohlnhöfer 2011, 236-39). Legitimate domestic order became characterized by the priorities of price stability, financial stability, and hence systemic stability, while rescues and stimulus were considered to be aberrant but necessary to sustain or restore legitimate socio-economic regulation, and redistribution.

The configuration of state preferences in Europe is less of a concern for Germany during a crisis situation. A look at international bargaining demonstrates that Germany, increasingly pressured by its economic contraction, its threatened financial system, and the world's economically powerful countries, assumed an assertive role to implement ordoliberal policies to address the crisis, though this was to benefit Europe as much as itself (Hübner 2012, 161-65). The German government relied on ordoliberal principles to make policy and explicitly attempted to affect European and global dynamics. The government stressed that the crisis was a result of flaws in the Anglo-American liberal market model, while maintaining that bailouts involved moral hazard and emphasizing the need for stricter regulation of financial markets and supervision of financial institutions (Schirm 2011, 53; Dyson 2010, 407). Often arguing against stimulus by governments and quantitative easing by key central banks, Merkel prioritized international institution building as a crisis response and played a leading role in negotiating the new European and global architecture for financial market regulation and supervision (Schirm 2011, 52; Dyson 2010, 401, 407). To stabilize the global economy, the government-primarily motivated by officials' principles-proposed to constrain non-bank activities by expanding regulation of the financial services sector, particularly new rules on hedge funds and credit rating agencies (Newman 2010, 159; Schirm 2011, 53). Germany also opposed unconventional ECB monetary policy operations. In June 2009, after the ECB Governing Council decided to purchase covered bonds, Merkel publicly warned about risks to ECB independence from international pressure (Dyson 2010, 408). Ordoliberal principles evidently formed the basis of the government's preferences and strategic response to the crisis. They were promoted for the benefit of Germany, Europe, and the global economy, despite controversy or contending arguments presented by other countries.

It is significant that the German government hardened its ordoliberal stance in a crisis situation because that indicates which policies will be preferred in the context of uncertainty. Although ordoliberal principles were prioritized and the configuration of state preferences in Europe was not a primary concern, the government believed that new institutions and regulations were necessary for the survival of EMU, so its commitment to the European project was apparent. Abraham Newman $(2010,153,155)$ argues that in situations of uncertainty "beliefs play a critical role in interest construction." He argues that the interwar and reunification experiences "elevated long-held beliefs about policy conservatism that now compete with the postwar multilateral policy frame within the foreign policy elite," which is indicative of the coupling of commitments, and these experiences put an emphasis on caution, or "the dangers associated with sudden change, loss of control and the benefits of incrementalism," evincing a commitment to ordoliberalism $(152-53,155)$. During the crisis, Newman finds that "[f]ar from abandoning the European project, Germany [was] more critical of potential free riding by other members" (154), which suggests that ordoliberal principles were prioritized to pressure governments to restrain spending and implement reforms, both which boost prospects for the long-term success of the project $(152,154)$. Germany rejected European proposals for solutions, did not prop up its main export market, and, despite a 20 percent fall in exports, "followed a 
politics of austerity, emphasizing monetary stability, moral hazard, and institutional constraints" (156-57, 161). The government argued against regional stimulus, stressed the exceptional and temporary nature of the crisis, and reinforced the need to use the SGP to enforce credible exits from stimulus, a position informed by a "broadly shared ideational consensus on fiscal discipline" and a desire to avoid inflation at all costs (Dyson 2010, 403; Schirm 2011, 55-56; Newman 2010, 158). During a crisis situation-like during a contingency situation-Germany is first concerned with national circumstances. But in a crisis the government prioritizes its traditional economic ideology, though in its concern for stability, responsibility, and strong institutions, its commitment to the advancement of integration and success of the European project is clear.

\section{Germany's Euro Crisis}

The German government's preferences have come under close scrutiny during the euro crisis which has intensified since early 2010. The crisis has fiscal roots in other countries, though Germany is primarily responsible for its management and German preferences drive its evolution. The application of ideational liberalism has demonstrated that in response to major events the government prefers to advance European integration according to ordoliberal principles, but while its commitment to the European project has remained stable over time, its commitment to ordoliberalism has wavered. This finding is significant because it helps to make sense of German policy making during the ongoing crisis. The fact that Germany's ordoliberal stance hardens during a crisis has policy implications for Eurozone governments. Given Germany's commitment to the European project, economic stagnation, rather than disintegration of the Eurozone, should be the primary concern for European policy makers. There are areas where the German government, which prescribes austerity over growth policies, is able and unable to compromise.

The reasons for the euro crisis in southern Europe are many-rescue packages and emergency fiscal policies, which resulted in major increases in public debt, following the global financial crisis certainly played a part - and the crisis is far from over. Greece, a peripheral economy that had borrowed beyond its means, attempted to conceal its circumstances by misreporting budget data. The crisis was triggered in January 2010 when the unsustainability of Greek debt was exposed. The height of the crisis came in May, when Eurozone countries led by Germany and the IMF approved a $€ 110$ billion bailout package coupled with austerity measures for Greece, breaking the Maastricht Treaty's no-bailout rule. Rising borrowing costs since early 2010 caused the public finances of Ireland and Portugal, which indulged in low interest rates during the previous decade, to deteriorate and both have had to be bailed out as well. Greece remains unable to afford to pay its creditors without the help of third parties. In February 2012, a second bailout worth $€ 130$ billion, conditional on a new package of austerity measures, was approved amid much doubt and hesitation on the part of Germany and other countries (Spiegel 2012). Some observers believe that Greece defaulting on its debts is inevitable. According to Jay Shambaugh, the Eurozone remains in "full-fledged crisis," which is really three interconnected crises. 
The euro area is currently involved in a banking crisis, where banks face a capital shortfall, interbank liquidity is restrained, and future losses are uncertain. It faces a sovereign debt crisis, where at least one country (Greece) will not pay its debts in full, and bondholders are displaying increasing concern about other sovereigns. It also, though, faces a macroeconomic crisis, where slow growth and relative uncompetitiveness in the periphery add to the burden of some of the indebted nations. (Shambaugh 2012, 1)

He argues that "a solution to one crisis will prove undone by the others unless all three are resolved" (1). Germany has to date focused almost exclusively on addressing the sovereign debt crisis with its austerity paradigm, which is underpinned by ordoliberal principles and applied even to situations in which high deficits are not caused by irresponsible government spending but rather higher borrowing costs since early 2010 and low international competitiveness, as in the cases of Italy and Spain.

Paying particular attention to its rigid ordoliberal stance, many observers have criticized the German government for muddling through the crisis instead of exhibiting leadership. Unlike in previous contingency and crisis situations, Germany's national circumstances-distinguished by restored growth, low unemployment, and large trade surpluses since 2009-may explain the government's slow reaction to the crisis. Elections in 2009 resulted in a centre-right coalition government, with the centre-right Free Democratic Party replacing the SPD as the junior partner to Merkel's Union. Highlighting that political infighting about adequate crisis management mechanisms is "intense" and the government's hesitant initial response toward supporting Greece created uncertainty, Kurt Hübner $(2012,161,166)$ argues that "[ $[$ t]he German approach to crisis management so far has added to the overall confusion and the nervousness of financial markets and even risks to prevent any stabilizing outcome of the current crisis." Hans Kundnani (2012) suggests that at each stage of the crisis, Merkel "has seemed to do the absolute minimum to keep the single currency together - but no more. This minimalist approach to the euro crisis may have ultimately cost Germany more in terms of bailouts than it would have if it had acted sooner and more decisively." He (2012) notes that Germany's ordoliberalism has kept inflation down and the euro weak, both which improve the global competitiveness of German exports but do not help other Eurozone countries with competitiveness and growth problems. ${ }^{5}$ In 2010, Germany experienced a growth rate of 3.6 percent, its highest since reunification (Young and Semmler 2011, 2). By 2012, it had the highest levels of employment since 1990 (Kundnani 2012). But while Germany is Europe's largest economy and top exporter, it is also the primary backstopper of other Eurozone countries. In return for support, the German government demands the implementation of austerity programs, which include spending cuts, tax increases, pension system overhauls, and labour market reforms. Following a record of low growth and almost no increases in living standards throughout the 1990s and early 2000s, Germany went through similar hardship to improve its economic prospects. The government's slow reaction to the crisis, then, may be reflective of social identities that evolved during that time. However, the government breached the original SGP to improve the country's prospects, so its prescriptions are not beyond criticism.

A commitment to ordoliberal principles is explicit, but a commitment to the European project is often only implicit. The German government's focus has been to use a combination of austerity and the European Financial Stability Facility (EFSF), a special purpose vehicle that

5. Inflation needs to increase moderately or the euro has to fall further, or both. 
provides up to $€ 440$ billion to indebted countries, "to deal with the solvency crisis and hope that by proving solvency, liquidity problems will ease" (Shambaugh 2012, 31-32). Merkel has maintained that Germany will neither issue Eurobonds, since they reduce incentives for indebted countries to pursue fiscal consolidation and increase the cost of financing German debt, nor permit any role for the ECB beyond its responsibility for monetary policy, but it supports the EFSF and a treaty to advance fiscal union (Gow 2011). The Fiscal Compact, which commits states to introduce national debt brakes, was signed in March 2012 by 25 of 27 EU countries and has already been ratified by several. Eurobonds, Merkel says, may be an option at a later stage of fiscal union (Gow 2011), which is sensible since, increased borrowing costs for Germany aside, "a system of ex ante control and veto, without which no Eurobond could be lastingly stable, requires political integration" (Pisani-Ferry 2012, 13). The ECB's independence is not an issue that can be affected, with neither positive nor negative stances tolerated by Merkel (Gow 2011). Finally, she has emphasized that, together with France and Italy, Germany would "do everything to defend the euro," though this would require strict actions by other Eurozone governments to abide by the rules of the SGP, which was revised again in March 2011 to include automatic sanctions for breaching deficit limits in some cases (Gow 2011). Many of these policy positions suggest a strong commitment to ordoliberalism; however, contributing significantly to the EFSF, advancing fiscal union, and the shift from a no-bailout clause to a bailout guarantee imply a willingness to go to great lengths to keep the Eurozone intact. Germany's commitment to Europe is particularly evident in its leadership in managing the Greek crisis. In March 2012, the biggest sovereign-debt restructuring in history wrote off $€ 100$ billion from Greece's debts of around $€ 350$ billion, imposing losses on private sector holders (The Economist 2012b). In 2011, such a restructuring had seemed very unlikely but Merkel pressed for the imposition of those losses.

\section{Collapse of the Euro?}

Germany's commitments to both ordoliberalism and the European project have been brought to the fore during the euro crisis, suggesting that German and European history warrants careful consideration. Scholars and other experts often reference historical events to make inferences about why governments act the way they do, but the direct influence of events is often overstated. The ideational commitments that result from historical events, rather, deserve more attention. Some might argue that Germany will not allow changes to the ECB's mandate because of its hyperinflation episode or that it is committed to Europe because it does not want to risk war on the continent. This is not entirely the case. The government learned lessons from historical events that prevent economic chaos and war but also instruct how to achieve economic prosperity and high levels of social well-being - these have been institutionalized to some extent in Germany. Two destructive world wars, hyperinflation, and division resulted in ideational commitments to ordoliberalism and the European project, which have helped Germany to become a leading economy and modern liberal democracy. The government has assumed the political responsibility to maintain unity in Europe and it believes an appropriate way to do this is by institutionalizing and exporting the economic ideas that have allowed Germany to succeed on the continent and globally. Case studies that assessed Germany's ideational commitments showed that the government consistently prefers advancing European integration regardless of national and international circumstances, though its ordoliberal stance has been relaxed because of domestic economic hardship and hardened in the context of crisis and uncertainty. 
The case studies of Germany breaking and revising the SGP and its management of the global financial crisis offer insight into the government's policy making during the euro crisis. The coupling of ideational commitments is apparent, with ordoliberalism prioritized because of uncertainty and a desire to facilitate natural, rather than stimulated, growth. Many observers predict that fragmentation or even disintegration of the Eurozone is imminent. Some argue that Germany is tired of funding Greece's debt and is increasing its demands for austerity to hurry Greece to default and exit the Eurozone (Booker 2012). Others argue that prescriptions for austerity, which the German government believes will keep the Eurozone together in the long term, will likely have the opposite effect (Reguly 2012). The case studies indicate that, in accordance with Germany's ideational commitments, the Eurozone will not fragment or disintegrate because Germany considers it to be part of a grand political project, meaning that the German government will attempt to avoid defaults and exits from the Eurozone even at high cost and risk. Germany considers the Eurozone to be irreversible and will go to great lengths to keep it together. Long-term stagnation in Greece and throughout the Eurozone-related to austerity prescriptions - is more likely.

Germany's crisis management style in the context of uncertainty is distinguished by a prioritization of ordoliberal principles. During the euro crisis, this has meant using an austerity paradigm in combination with the EFSF and a proscription of ECB intervention. All problems and contingencies during the crisis, even those that do not involve profligacy, are addressed by the same policy paradigm with an overemphasis on deficit cutting (Pisani-Ferry 2012, 2-4, 1315). The government's entrenched, much-criticized ordoliberal stance is a strategic response to prolonged uncertainty. Hübner $(2012,159,170-75)$ argues that "Germany's insistence in its own interests and norms hinders the delivery of a comprehensive crisis management of the Eurozone crisis." The implementation of austerity packages in exchange for German support sometimes creates tension and conflict in the Eurozone-best illustrated by Athens burning and massive protests in Spain-because packages include the prioritization of fiscal consolidation and, relatedly, severe cuts to pensions, public services, and education spending. International bargaining, particularly on the issue of making the ECB the lender of last resort, has not led to the sustained cooperation that might motivate Germany to relax its ordoliberal stance. Uncertainty about the inability or unwillingness of indebted governments to implement reforms remains. According to ideational liberalism, the configuration of state preferences during a crisis is not a significant influence on German preference formation. Domestic actors such as Merkel, political parties, and the German Supreme Court have played key roles in state preference formation, while France has had little influence (167-68). A notable break from ordoliberalism is Merkel's criticism of the European Commission's call for Eurobonds, which diminishes the ability of the EU to project itself as an autonomous political entity (169-70). Germany's crisis management style at times exacerbates the crisis and subsequently put the viability of the European project into question.

\section{Age of Austerity}

With the onset of the euro crisis, the Eurozone entered an age of austerity characterized by restrained public spending, high unemployment, low growth, and much uncertainty. The facts that Germany couples its ideational commitments and its commitment to ordoliberalism wavers can be taken into account in the development of strategies to govern the crisis in a way that can lead to growth, which ultimately underpins sovereign debt sustainability and the strength of 
banks. To solve the sovereign debt crisis, Eurozone countries have several options: fiscal consolidation, inflating away debt, growth, default, or a mix of these choices. Taking a hard ordoliberal stance, Germany is only willing to move forward with fiscal consolidation strategies, understanding that these will break cycles of debt, reassure the private sector, and ultimately result in sustainable growth. It is indisputable that sustained fiscal consolidation is necessary to bring sovereign debt under control (Pisani-Ferry 2012, 9). Paul Krugman (2012), however, draws attention to the facts that large spending cuts have not resulted in a surge in consumer and business confidence while Ireland and Portugal, which have implemented austerity programs, still face high borrowing costs because their economies remain depressed, which undermines tax bases to the extent that debt-to-GDP ratios are deteriorating. Italy and Spain deserve special attention because, unlike Greece, they are core economies that can put extreme pressure on the Eurozone if long-term stagnation does occur. Greece is a different case because it was profligate, hence austerity is non-negotiable, but these other countries need help bringing down interest rates and increasing tax receipts, which means improving growth. A mix of the aforementioned choices is therefore necessary.

The German government could unilaterally relax its ordoliberal stance and promote growth on the understanding that without it the sovereign debt crisis will persist. According to Shambaugh $(2012,32)$, focusing on austerity and the EFSF is only sensible if the problem is profligacy-if the problem is either due to high interest rates or slow growth, then different solutions are required. One way to promote pan-European growth is to be more flexible on the issues of the ECB's bond-buying program and inflation. The ECB has already purchased billions worth of covered bonds and lent over $€ 1$ trillion to banks to purchase government bonds. To reduce debt and spur growth, Shambaugh (2012, 36-37) recommends that the ECB increase its asset purchases, lower long-term interest rates, lift its inflation target, announce that it will keep longterm interest rates within a reasonable range for countries in good fiscal standing or that are following an EFSF/IMF package, and maximize its bond buying by clarifying its goals for lower long-run bond yields. Ending Germany's opposition to the ECB's program would not only be in line with preserving central bank independence but also improve European growth prospects. It may additionally encourage Germans to save less and consume more. Germany has one of the highest saving rates of all developed countries, so its citizens would lose some of their savings with even a moderate rise in inflation (Hung 2011; Kundnani 2012). Kundnani (2012) argues that Germany's hawkishness on inflation does not make sense as a strategy in current circumstances because it means there is no solution for indebted countries except for ever greater austerity. Higher inflation and slower debt consolidation in Germany can boost demand there, which would address the problem of current account imbalances and reinforce growth potential across Europe. The German government resists such policies since it wants to set an example of budget discipline, has an aversion to inflation and central bank intervention, and refuses to compromise its competitiveness (The Economist 2012a). The configuration of state preferences largely does not matter to Germany, but the potential scale of the crisis demands a clear break from ordoliberal orthodoxy and the austerity paradigm in use. Since it improves prospects for the success of the European project, growth is ultimately in Germany's best interests.

As Merkel maintains, other countries must also do their part. Reducing the uncertainty that hardens Germany's ordoliberal stance and proposing growth policies that may persuade the German government to be more flexible are two strategies that can increase awareness in Germany that austerity is not enough. Indebted governments can reduce uncertainty by showing that they too are committed to the European project. For instance, politicians must be willing to 
make sacrifices to increase wage flexibility and reform product and service markets. Guérot and Dullien (2012) argue that Germany's commitment to ordoliberalism has "genuine political support and coherent intellectual foundations," so instead of attacking excessive austerity and suggesting a renegotiation of the Fiscal Compact, countries could demand pan-European growth and investment programs with more spending and taxation power shifted to the EU level, propose that unused funds should be channelled into the private sectors of peripheral economies, and ask for more time to balance budgets. Such strategies could lead to increased flexibility in Germany and sustainable growth in Europe. In demanding growth, the governments of Italy and Spain could equate their fiscal and competitiveness problems with Germany's experience with reunification costs, Agenda 2010, and revising the SGP to demonstrate that flexibility is important in short- and medium-term plans. Countries could also propose their own credible plans for fiscal consolidation that are linked to Europe 2020, the ten-year comprehensive growth framework proposed by the European Commission and adopted by EU governments in July 2010, and compare them with Germany's recommendations to try and reach a viable middle ground. Governments cannot leave the framework unimplemented, like too many did with the Lisbon Agenda proposed a decade earlier. Together with German efforts to increase flexibility and promote growth, such changes could make the ongoing crisis more predictable and more manageable.

\section{ACKNOWLEDGEMENTS}

The author would like to thank David Long and Dane Rowlands for their excellent guidance, Achim Hurrelmann, Patrick Leblond, Georg Witschel, and two anonymous reviewers for their thoughtful criticism, and Andrzej and Genia Olender for their inspiration and support.

\section{REFERENCES}

Allen, Christopher S. 2005. "Ordo-Liberalism Trumps Keynesianism: Economic Policy in the Federal Republic of Germany and the EU." In Monetary Union in Crisis: The European Union as a Neo-liberal Construction, edited by Bernard H. Moss, 199-221. Basingstoke: Palgrave Macmillan.

- 2010. "Ideas, Institutions and Organized Capitalism: The German Model of Political Economy 20 Years after Reunification.” German Politics and Society 28 (2): 130-50.

Booker, Christopher. 2012. "The European Project is Splitting Apart at the Very Core." Telegraph, February 18. http://www.telegraph.co.uk/comment/columnists/christopherbooker/9090332/The-Europeanproject-is-splitting-apart-at-the-very-core.html.

Chandler, William M. 2002. "German Influence in Shaping EMU: Still a Tamed Power?" In The Euro: European Integration Theory and Economic and Monetary Union, edited by Amy Verdun, 201-14. Lanham: Rowman \& Littlefield.

Chang, Michele. 2006. "Reforming the Stability and Growth Pact: Size and Influence in EMU Policymaking.” European Integration 28 (1): 107-20. 
Dyson, Kenneth. 2002. "Germany and the Euro: Redefining EMU, Handling Paradox, and Managing Uncertainty and Contingency." In European States and the Euro: Europeanization, Variation, and Convergence, edited by Kenneth Dyson, 173-211. Oxford: Oxford University Press.

. 2008. "Germany: A Crisis of Leadership in the Euro Area." In The Euro at 10: Europeanization, Power, and Convergence, edited by Kenneth Dyson, 132-64. New York: Oxford University Press.

- 2010. "In the Shifting Shadows of Crisis: Pivot Points, Crisis Attribution, and MacroEconomic Policies under Grand Coalition." German Politics 19 (3-4): 393-415.

Guérot, Ulrike, and Sebastian Dullien. 2012. "Why Berlin is Fixed on a German Solution to the Eurocrisis." Guardian, March 2. http://www.guardian.co.uk/commentisfree/2012/mar/02/german-solution-to-eurozone-crisis.

Gow, David. 2011. "Fear Sweeps Markets as Germany Rules Out ECB Intervention." Guardian, November 24. http://www.guardian.co.uk/business/2011/nov/24/germany-rules-out-ecbintervention.

Hübner, Kurt. 2012. "German Crisis Management and Leadership_From Ignorance to Procrastination to Action." Asia Europe Journal 9: 159-77.

Hung, Jochen. 2011. "German Aversion to the ECB Printing Money Isn't about the 'National Psyche'." Guardian, December 22. http://www.guardian.co.uk/commentisfree/2011/dec/22/germany-ecb-national-psychehyperinflation.

Jeffery, Charlie, and William E. Paterson. 2004. "Germany and European Integration: A Shifting of Tectonic Plates." In Germany: Beyond the Stable State, edited by Herbert Kitschelt and Wolfgang Streeck, 59-75. London: Frank Cass.

Kaltenthaler, Karl. 2002. "German Interests in European Monetary Integration." Journal of Common Market Studies 40 (1): 69-87.

Katzenstein, Peter J. 1997. "United Germany in an Integrating Europe." Current History 96 (608): 116-23.

Kitschelt, Herbert, and Wolfgang Streeck. 2004. "From Stability to Stagnation: Germany at the Beginning of the Twenty-First Century." In Germany: Beyond the Stable State, edited by Herbert Kitschelt and Wolfgang Streeck, 1-34. London: Frank Cass.

Krugman, Paul. 2012. "Pain without Gain.” New York Times, February 19. http://www.nytimes.com/2012/02/20/opinion/krugman-pain-without-gain.html?_r=2.

Kundnani, Hans. 2012. "The Eurozone Will Pay a High Price for Germany's Economic Narcissism." Guardian, January 6.

http://www.guardian.co.uk/commentisfree/2012/jan/06/eurozone-germany-ordoliberalism.

Lorca-Susino, María. 2010. The Euro in the 21st Century: Economic Crisis and Financial Uproar. Farnam: Ashgate.

Moravcsik, Andrew. 1997. "Taking Preferences Seriously: A Liberal Theory of International Politics." International Organization 51 (4): 513-53.

Newman, Abraham L. 2010. "Flight From Risk: Unified Germany and the Role of Beliefs in the European Response to the Financial Crisis." German Politics and Society 28 (2): 151-64.

Pisani-Ferry, Jean. 2012. "The Euro Crisis and the New Impossible Trinity." Bruegel Policy Contribution, Issue 2012/01, Bruegel, Brussels. http://www.bruegel.org/download/parent/674the-euro-crisis-and-the-new-impossible-trinity/file/1540-the-euro-crisis-and-the-newimpossible-trinity. 
Reguly, Eric. 2012. "Germany's Hard Line Pushes Euro Zone to the Edge." Globe and Mail, February 13. http://www.theglobeandmail.com/report-on-business/commentary/ericreguly/germanys-hard-line-pushes-euro-zone-to-the-edge/article2334717.

Reiter, Heinz, and Matthias Schmolz. 1993. "The Ideas of German Ordoliberalism 1938-45: Pointing the Way to a New Economic Order." European Journal of the History of Economic Thought 1 (1): 87-114.

Schirm, Stefan A. 2011. "Varieties of Strategies: Societal Influences on British and German Responses to the Global Economic Crisis." Journal of Contemporary European Studies 19 (1): 47-62.

Shambaugh, Jay C. 2012. "The Euro's Three Crises.” Brookings Papers on Economic Activity, Brookings Institution, Washington, DC.

http://www.brookings.edu/ /media/Files/Programs/ES/BPEA/2012_spring_bpea_papers/2012 _spring_BPEA_shambaugh.pdf.

Spiegel, Peter. 2012. "Greek Debt Nightmare Laid Bare." Financial Times, February 21. http://www.ft.com/intl/cms/s/0/b5909e86-5c0f-11e1-841c00144feabdc0.html\#axzz1mulvgHxo.

The Economist. 2012a. "Charlemange: Still Sickly.” March 31. http://www.economist.com/node/21551495.

_. 2012b. "Greece's Default: The Wait Is Over." March 17. http://www.economist.com/node/21550271.

Verdun, Amy. 2009. "Economic Developments in the Euro Area." Journal of Common Market Studies 47 (s1): 233-57.

White, Lawrence H. 2012. “The Postwar German 'Wonder Economy' and Ordoliberalism.” In The Clash of Economic Ideas: The Great Policy Debates and Experiments of the Last Hundred Years, 231-45. Cambridge: Cambridge University Press.

Wiesenthal, Helmut. 2004. "German Unification and 'Model Germany': An Adventure in Institutional Conservatism." In Germany: Beyond the Stable State, edited by Herbert Kitschelt and Wolfgang Streeck, 34-54. London: Frank Cass. 
Correct citation: Olender, Michael. 2012. "Germany's Euro Crisis: Preferences, Management, and Contingencies." Review of European and Russian Affairs 7 (2): 1-17.

Published by the Centre for European Studies at Carleton University, Ottawa, Canada.

Available online at: www.carleton.ca/rera/

RERA is an electronic academic peer-reviewed journal that publishes graduate, post-graduate, and young scholarly works. Topics relate to the European Union, its Member States, the former Soviet Union, and Central and Eastern Europe. The journal is a joint project supported by the Canada-Europe Transatlantic Dialogue - a cross-Canada research network supported by the Social Sciences and Humanities Research Council of Canada (SSHRC) — along with the Institute of European, Russian and Eurasian Studies (Carleton University) and its associated research unit, the Centre for European Studies.

RERA aims to provide an accessible forum for research, to promote high standards of research and scholarship, and to foster communication among young scholars.

\section{Contact:}

Carleton University

The Centre for European Studies

1103 Dunton Tower

1125 Colonel By Drive

Ottawa, ON

K1S 5B6

Canada

Tel: +01 613 520-2600 ext. 1179; E-mail: rera-journal@ carleton.ca

\section{Creative Commons License}

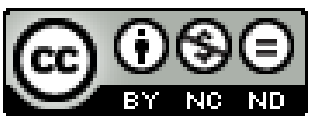

http://creativecommons.org/licenses/by-nc-nd/3.0/

This Working Paper is licensed under a Creative Commons Attribution-Non-CommercialNo Derivs 3.0 Unported License (CC BY-NC-ND 3.0).

Articles appearing in this publication may be freely quoted and reproduced provided the source is acknowledged. No use of this publication may be made for resale or other commercial purposes.

ISSN: $1718-4835$

(C) 2012 The Author(s) 